\title{
Colony-based foraging segregation by Antarctic fur seals at the Kerguelen Archipelago
}

\author{
Mary-Anne Lea ${ }^{1, *}$, Christophe Guinet ${ }^{2}$, Yves Cherel ${ }^{2}$, Mark Hindell ${ }^{1}$, \\ Laurent Dubroca ${ }^{2}$, Sam Thalmann ${ }^{1}$
}

${ }^{1}$ Antarctic Wildlife Research Unit, School of Zoology, University of Tasmania, PO Box 252-05, Hobart, Tasmania 7001, Australia ${ }^{2}$ Centre d'Etudes Biologiques de Chizé-CNRS, 79360 Beauvoir-sur-Niort, France

\begin{abstract}
The foraging behaviour of conspecific female Antarctic fur seals (AFS) was compared simultaneously at 2 breeding colonies at Îles Kerguelen (S Indian Ocean). A remnant colony at ÎIes Nuageuses (IN) thought to have escaped sealing is hypothesized to be the source of increasing fur seal numbers at Cap Noir $(\mathrm{CN})$ on the Kerguelen mainland. Inter-annual variability in foraging areas is known to occur in response to local oceanographic changes at CN. Given the distance between the 2 sites $(\sim 160 \mathrm{~km})$, we hypothesize that seals from the 2 colonies may show spatial segregation in foraging due to variability in local prey resource availability, although the transfer of foraging knowledge between sites via emigration may override such behaviour. The foraging zones, diving activity, diet and foraging success of seals were compared between sites using satellite telemetry, dive recorders and faecal analysis. No evidence of spatial foraging overlap was observed, with seals from IN conducting longer foraging trips, typified by a longer initial transit phase, than CN seals, which spent less time diving at night and dived more deeply. Pups nevertheless received higher absolute and daily energy delivery rates at IN. Diet was superficially similar at $\sim 98 \%$ myctophid consumption; however, IN seals favoured the high-energy Gymnoscopelus nicholsi, indicating that local heterogeneity in marine resources likely influences the foraging zone choice of AFS. Finally, distribution patterns of 54 female AFS tracked during summer months from 1998 to 2006 reveal the importance of both on-shelf $(<500 \mathrm{~m})$ and shelf-break regions as foraging habitat. The core foraging area for $\mathrm{CN}$ in all years $\left(10400 \mathrm{~km}^{2}\right)$ was small $(\sim 10 \%$ of total foraging space); however, time spent in this region alone totaled $38 \%$. The likelihood of spatial overlap in foraging range is higher on the east coast of Kerguelen.
\end{abstract}

KEY WORDS: Fur seal $\cdot$ Segregation $\cdot$ Myctophid $\cdot$ Diving $\cdot$ Southern Ocean

\section{INTRODUCTION}

Intra-specific spatial and dietary segregation is common between the sexes and the different age classes of top level marine predators like seals (Sterling \& Ream 2004, Page et al. 2006), seabirds (Baird 1991) and penguins (Forero et al. 2002). Such differences may be explained by variation in body size and, consequently, diving ability, or in relation to temporal constraints on foraging behaviour related to breeding (Salamolard \& Weimerskirch 1993, Charrassin et al. 1998), as in the case of central place foragers (Orians \& Pearson 1979). High latitude species in particular, such as seals and penguins, exhibit foraging plasticity both within and between sites in response to changes in physical oceanography and associated marine productivity (McCafferty et al. 1998, Tremblay \& Cherel 2003, Lea et al. 2006, Trathan et al. 2006). Favourable foraging and reproductive success are likely positively influenced by the prevalence of proximal and/or predictable concentrations of prey (Mori \& Boyd 2004, Trathan et al. 2006). Temporal and spatial variability in marine productivity and availability also influence individual and colony-wide foraging behaviour, while competition between similar niche species may be equally important in regulating foraging 
activity (Barlow et al. 2002). At sub-Antarctic South Georgia Island, where the majority of predators feed on Antarctic krill Euphausia superba during summer months, macaroni penguins Eudyptes chrysocome are a case in point. Penguins tracked from adjacent islands show considerable foraging overlap, while those from more distant breeding sites displayed no overlap whatsoever. A 7 yr study of foraging habitat at one breeding site helped interpret these data. In all years, penguins concentrated their foraging efforts on a bearing to the north of the colony, only varying the distance out to the shelf between years (Trathan et al. 2006), suggesting that inter-annual variability in shelf prey availability determined the extent of foraging movements.

Few sympatric, conspecific comparisons of pinniped, and particularly, otariid, foraging distribution patterns have been undertaken. Northern fur seals Callorhinus ursinus in northern sub-polar regions display a high degree of individual (Call et al. in press) and colonyrelated foraging site fidelity (Robson et al. 2004) during summer foraging trips, although the degree of overlap varies temporally within a season and between years (Call et al. in press). Again, at South Georgia, female Antarctic fur seals Arctocephalus gazella (AFS) from 2 colonies located only $90 \mathrm{~km}$ apart exhibited no spatial overlap, even though their potential foraging range was up to $300 \mathrm{~km}$ (Boyd et al. 2002).

At sub-Antarctic Îles Kerguelen, AFS numbers are recovering after considerable sealing pressure in the 1800s (Budd \& Downes 1969). Breeding individuals on the Courbet Peninsula of Kerguelen were first discovered in the early 1980s (Bester 1981) and are thought to have immigrated from a remnant population in the northwestern sector of Îles Kerguelen (Bester 1981), subsequently shown to be at Îles Nuageuses (IN) (Jouventin et al. 1982). Studies of female AFS foraging behaviour conducted on the Courbet Peninsula between 1998 and 2000 have established high individual foraging-site fidelity (Bonadonna et al. 2001) and a strong correlation between many foraging parameters and change in environmental parameters such as sea surface temperature, the location of frontal structures, distance to the colony and the distribution of fish prey resources (Guinet et al. 2001, Lea \& Dubroca 2003, Lea et al. 2006). To date, no studies of the foraging behaviour of seals from the remnant IN population have been undertaken. Given the inter-annual variability in foraging success exhibited by AFS at Cap Noir (CN) in response to changing oceanographic conditions and prey availability (Lea et al. 2006), and the foraging habitat preferences predicted for central place-foraging female AFS by Guinet et al. (2001), segregation in foraging distribution and diet may well be expected between the 2 colonies if prey availability is sufficient.
Previous foraging studies of AFS females from the $\mathrm{CN}$ breeding colony indicate that an area extending from the northeast to the east of the colony is an important foraging area (Lea et al. 2006). Given the potential importance of the IN population to the recolonisation of the Courbet Peninsula at Îles Kerguelen and the proximity of the 2 islands within the foraging range previously recorded for AFS at Îles Kerguelen (Bonadonna et al. 2001, Guinet et al. 2001, Lea et al. 2006), some overlap in foraging habitat between sites may also be expected to occur. Consequently, the primary aim of this study was to determine whether the AFS population at IN displays evidence of foraging segregation in terms of spatial foraging distribution, dive behaviour, foraging success (such as pup mass gain) and diet in comparison to seals from the derivative colony at $\mathrm{CN}$.

\section{MATERIALS AND METHODS}

Study sites and population size. The Kerguelen Archipelago $\left(49^{\circ} 20^{\prime} \mathrm{S}, 70^{\circ} 20^{\prime} \mathrm{E}\right)$ in the southern Indian Ocean (Fig. 1) is comprised of approximately 300 islands with a combined coastline greater than $3000 \mathrm{~km}$. One of the most isolated land masses on Earth, it is located more than $3000 \mathrm{~km}$ from both Africa and Australia, and approximately $2200 \mathrm{~km}$ north of Antarctica.

The 2 study colonies were located $164 \mathrm{~km}$ apart at $\mathrm{CN}\left(49^{\circ} 07^{\prime} \mathrm{S}, 70^{\circ} 45^{\prime} \mathrm{E}\right)$ on the northeast coast of the Courbet Peninsula ( $\mathrm{CN}$, the site of a 3 yr study) and at Île de Croy $\left(48^{\circ} 38^{\prime} \mathrm{S}, 68^{\circ} 38^{\prime} \mathrm{E}\right.$, IN, Fig. 1) in the IN. The colony at CN currently extends along the coast over a distance of approximately $1 \mathrm{~km}$. Seals breed on pebbly beaches with mothers and pups moving onto the Cotula plumosa covered slopes and plateau as pups become more independent from their mothers. At the rarely visited IN colony, the majority of breeding activity is centred around a small, protected bay on the east coast of the island. In 1984 seals were reported as breeding on the headlands north and south of the bay and on an offshore islet to the southeast, with an estimated 1500 females on the headlands and over 5000 seals in total (Jouventin \& Stonehouse 1985). The IN colony was visited from 5 to 20 January 2000, while an ongoing study was conducted at $\mathrm{CN}$ from December 1999 to March 2000. Analyses are restricted to the common period of 5 to 20 January 2000 in early summer.

Systematic whole colony counts of tagged and untagged pups at $\mathrm{CN}$ were made in late January in 1999 and 2000 as part of an ongoing 3 yr study (1998 to 2000) at this site (see Table 1 and Lea et al. 2006). 


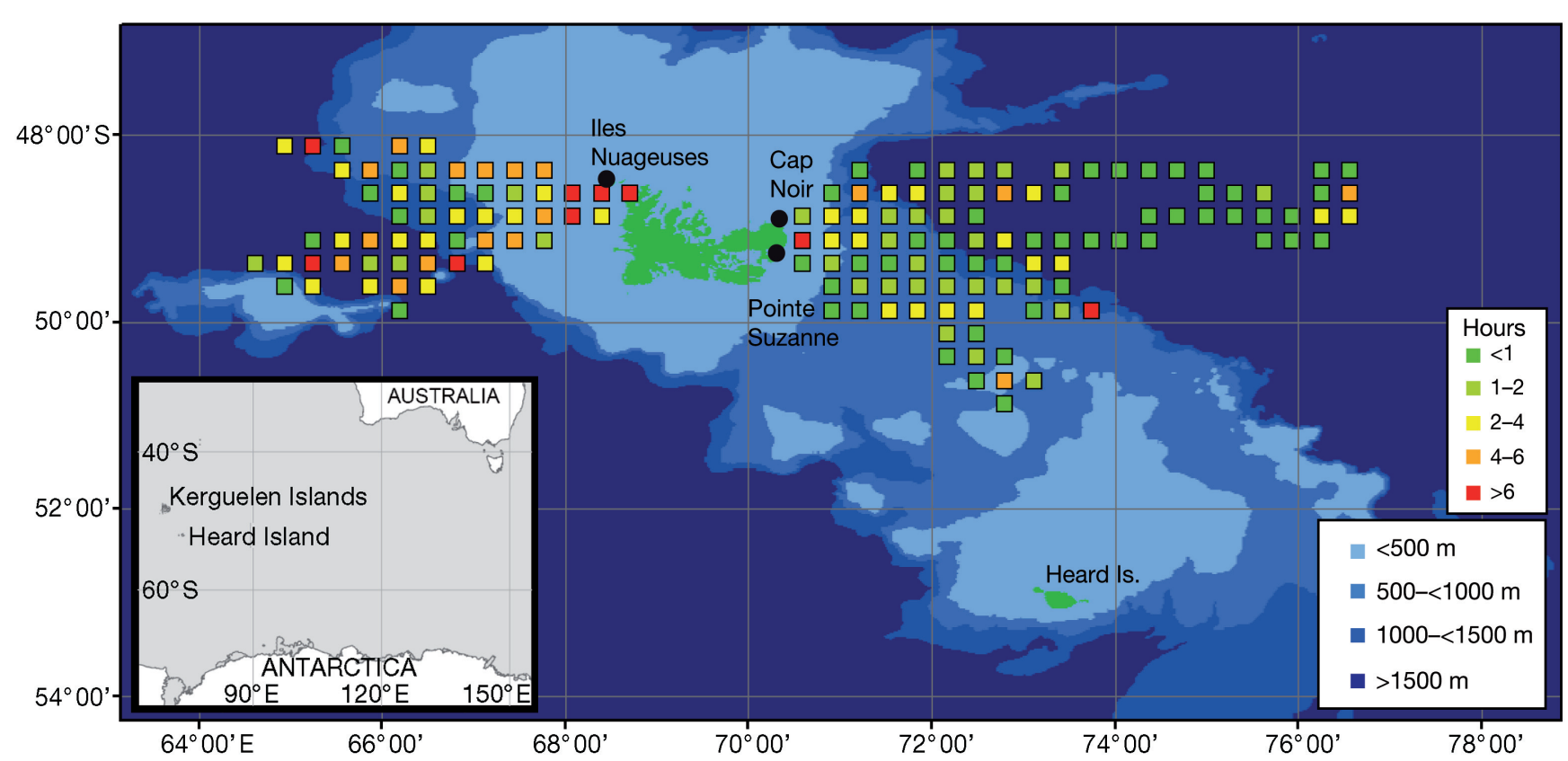

Fig. 1. Arctocephalus gazella. Time spent per $20 \times 20 \mathrm{~km}$ grid cell for female Antarctic fur seals from l̂les Nuageuses (west, $\mathrm{n}=5$ ) and Cap Noir (east, $n=7$ ) in January 2000. Time spent (seal hours) is weighted by the number of seals and calculated for each colony separately. Inset map 13134 (Edition 1) courtesy of the Australian Antarctic Data Centre

A simplified mark-recapture technique using the number of flipper-tagged pups resighted as a proportion of those known to be tagged was used as a correction for counts of untagged pups. At IN, a single count of unmarked pups on the beaches and tussocks was made on 18 January 2000. A factor of 4.1 was used to convert pup counts to population size (Page et al. 2003).

Foraging activity. Time-depth recorders (TDRs, Wildlife Computers) or a TDR and platform terminal transmitter package (ST-10 PTT, Telonics Pty, packaged by Sirtrack) linked to the ARGOS satellite system were deployed on adult females to study the diving activity and foraging distribution of the seals (see Bonadonna et al. 2000, Guinet et al. 2001, Lea et al. $2002 b$, 2006). Seals were captured ashore using a hoop net and were subsequently weighed, a standard length measurement was recorded (nose to tail in ventral recumbancy) and an individual number was applied to

Table 1. Arctocephalus gazella. Pup production counts at Cap Noir (CN) and Île de Croy (Îles Nuageuses) breeding colonies in 1999 and 2000

\begin{tabular}{|lcccccc|}
\hline Date & Size & \multicolumn{2}{c}{$\begin{array}{c}\text { Pups counted } \\
\text { Tagged Untagged }\end{array}$} & $\begin{array}{c}\text { Actual no. } \\
\text { tagged pups }\end{array}$ & $\begin{array}{c}\text { Estimated pup } \\
\text { production }\end{array}$ & $\begin{array}{c}\text { Est. colony } \\
\text { Size }\end{array}$ \\
\hline 22 Jan 1999 Cap Noir & 130 & 545 & 140 & 724 & 2968 \\
29 Jan 2000 & Cap Noir & 137 & 512 & 158 & 748 & 3067 \\
18 Jan 2000 & Île de Croy & - & 3279 & - & $\sim 3600^{\text {a }}$ & 14700 \\
additional pups seen on inaccessible islet in east harbour & & \\
\hline
\end{tabular}

the fur on the rump with peroxide hair-dye (BristolMyers Squibb). During the attachment of the devices, adult seals were held on a wooden restraint board. Following the deployment, which lasted an average of 15 to $20 \mathrm{~min}$, seals were released with their pups. The colonies were checked at least twice daily for the return of marked females overnight (0800) and during the day (1900).

Three types of dive recorders were deployed on seals from the 2 sites in January 2000. A single Mk7 TDR was attached dorsally to the fur $10 \mathrm{~cm}$ anterior to the rump of 9 seals at IN and 10 seals at CN using 2part Araldite (AW 2101, Ciba Specialty Chemicals) for the study of diving behaviour. TDR/PTT packages were also deployed on seals at both sites for the study of at-sea distribution patterns. At CN, Mk7 TDR/PTT packages (Lea \& Dubroca 2003) were deployed on 8 seals, while at IN, Mk5 TDR/PTT packages (Bonadonna et al. 2000, Guinet et al. 2001) were deployed on 7 seals (Table 1). Relatively large seals with healthy pups were selected for these deployments. These packages were attached dorsally between the scapulae.

In total, devices were attached to 33 seals (15 at IN and 18 at $\mathrm{CN})$. During the course of the study 1 seal returned without the TDR/ PTT device $(\mathrm{CN}), 1$ seal was not 
recaptured and thus PTT data were available without dive data (IN), and in 4 cases (2 per colony), the Mk7 TDR failed to record dive data. PTTs (2 MK10-A satellite GPS tags, Wildlife Computers, and 3 ST-10 PTT) were also deployed on 16 females at Pointe Suzanne on the southeastern Courbet Peninsula from 22 January to 21 February 2006. The movements of these adult females, together with those at IN (from 2000) and CN (from 1998 to 2000), constitute the total tracking research undertaken at Îles Kerguelen and consequently provide the most complete island-wide estimate of foraging habitat use.

Transit and foraging phases were determined from the onset and ending of bout diving during the foraging trip (see Lea et al. 2002b for bout analysis details). Inter-site comparisons of diving behaviour have been restricted to those seals at each site carrying the small, rump-mounted Mk7 TDRs to minimize the device effects associated with carrying larger PTTs. An analysis of similarity (ANOSIM) and a similarity of percentages (SIMPER) analysis with site as a factor were conducted using PRIMER 5.0 (Primer-E Limited). Seven dive parameters were included in the analyses: mean dive depth $(\mathrm{m})$, dive duration $(\mathrm{min})$, foraging trip length (d), proportion of time spent diving, proportion of dives in bouts, mean dives per bout and dive frequency $\left(\mathrm{h}^{-1}\right.$, see Lea et al. 2002b for greater detail). Proportional data were arcsine-transformed and other data were log-transformed.

Spatial analyses. Argos movement data of location quality 0 to 3 (see Bonadonna et al. 2001) were filtered for an upper speed of $3.0 \mathrm{~m} \mathrm{~s}^{-1}$ using the filtering algorithm in the R-Software Trip package (Sumner 2006). The resulting track was split into 60 min segments, which were then summed within $20 \times 20 \mathrm{~km}$ grid cells to create time spent in area plots for habitat use. Time spent in cells was converted to a proportion by colony or year to standardize effects of sample size for the various deployments. The centroid of the $20 \times 20 \mathrm{~km}$ grid cells was spatially joined in ArcMap (ESRI) to the nearest bathymetry value (GEBCO One Minute Grid) to provide a water depth measurement per cell. Bathymetric domains were defined as inner shelf $(<500 \mathrm{~m})$, outer shelf $(500$ to $1000 \mathrm{~m})$, shelf break (1000 to $1500 \mathrm{~m})$, and deep waters (>1500 m).

Diet. Faecal samples were collected from female haul-out sites in the colonies at $\mathrm{CN}$ and IN during the course of the study (6 January to 23 January 2000). Individual samples were frozen at $-20^{\circ} \mathrm{C}$ on site and returned to the laboratory for sorting and prey identification. Samples were elutriated overnight and subsequently sieved with a $1 \mathrm{~mm}$ and $500 \mu \mathrm{m}$ mesh. The frequency of occurrence (FO) of fish (otoliths, scales and bones), squid (beaks, radulas, pens and eye lenses), invertebrates (amphipods, isopods, nematodes and annelids) and other miscellaneous items in faeces was noted. Percentage FO is expressed as a percentage of the number of faeces containing prey items. Numerical abundance of fish and squid was estimated by the sorting and identification to species level of otoliths (sagitta, asteriscus and lapillus) when possible. See Lea et al. 2002a for further details.

Dietary comparisons between sites were conducted using a stepwise Discriminant Function Analysis (Systat 9.0, SPSS) with tolerance level set at 0.15 and $p$ values of 0.05 . Measures of mass gain were compared between sites using a 2 -sample $t$-test. All variables were tested for normality and homogeneity of variance with Levene's statistic.

Foraging success. Inter-site comparisons of pup mass: A random cross-sectional sample of pups ( $\mathrm{n}=$ 100) was weighed at each breeding site on 14 January 2000 to test for differences in mean size of pups between populations. Pups were weighed using a Salter Weightronix spring balance $(25 \pm 0.02 \mathrm{~kg})$ by field teams moving systematically through the colony to prevent the repeat weighing of individuals. Comparisons were made per sampling period by 2-way ANOVA on log-transformed mass data with 'sex' and 'site' as factors (SPSS).

Pup mass gain per foraging cycle: Mass gained by a pup during a foraging cycle (1 foraging trip and subsequent shore bout) has been shown to represent a relatively easily obtainable measure of maternal energy transfer to the pup in several studies (Georges \& Guinet 2000, Guinet et al. 2000). The pups of females equipped with PTT and/or TDRs were weighed each day during the fasting period while females were at sea, prior to the arrival of the female and again immediately after her departure, to estimate the mass gained by the pup during the foraging cycle (FC). In instances where the body mass was not recorded on the arrival day of the female, it was estimated by linear regression of pup mass lost during the previous fasting bout. A control group consisting of pups from unequipped females was also monitored simultaneously at each colony (IN: $\mathrm{n}=12 ; \mathrm{CN}: \mathrm{n}=21$ ).

\section{RESULTS}

\section{CN-IN comparison}

\section{Foraging habitat use}

There was no overlap in the foraging zones used by seals tracked simultaneously at IN $(\mathrm{n}=5)$ and $\mathrm{CN}$ ( $n=7$ ) in January 2000 (Fig.1). Seals from the CN colony foraged within a $\sim 240 \mathrm{~km}$ arc from the NE to the SE of the island (Table 2, Fig. 1), whilst the majority of 


\begin{tabular}{|c|c|c|c|c|}
\hline 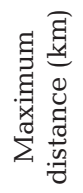 & $\begin{array}{lllllll}1 & 1 & 1 & 1 & 1 & 1 & 1\end{array}$ & 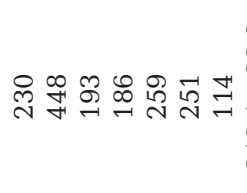 & $\begin{array}{lllllll}1 & 1 & 1 & 1 & 1 & 1 & 1\end{array}$ & 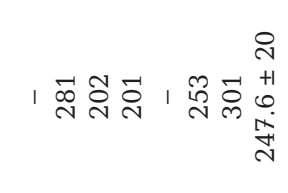 \\
\hline 吾 & O료 & 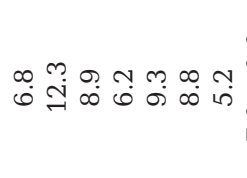 & : & 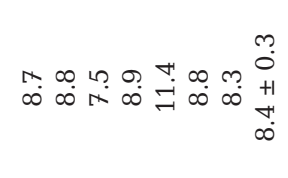 \\
\hline 草 & $\lambda_{1} \lambda_{1} \lambda_{\lambda} \lambda_{\lambda} \lambda_{1} \lambda_{1}$ & $\lambda \gg \lambda \lambda \gg \lambda \lambda$ & 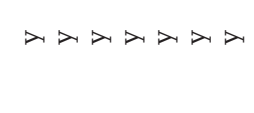 & $\lambda_{1} \lambda_{1} \lambda_{1} \lambda_{1} \mid \lambda_{1}$ \\
\hline$\stackrel{E}{E}$ & $\begin{array}{lllllll}1 & 1 & 1 & 1 & 1 & 1 & 1\end{array}$ & $\lambda_{1} \lambda_{\lambda} \lambda_{\lambda} \lambda_{\lambda} \lambda_{1}$ & $\begin{array}{lllllll}1 & 1 & 1 & 1 & 1 & 1 & 1\end{array}$ & $\left|\lambda_{1} \lambda_{1} \lambda_{1}\right| \lambda_{1} \lambda_{1}$ \\
\hline 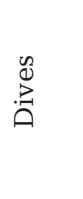 & 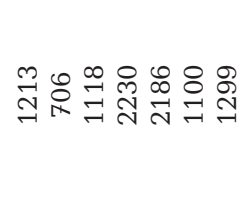 & 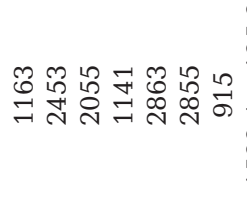 & 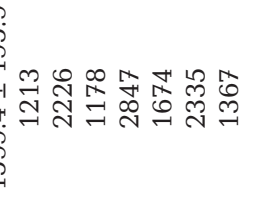 & 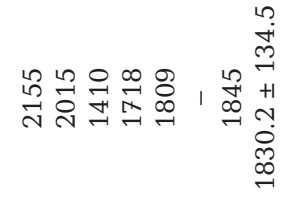 \\
\hline 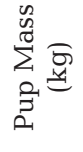 & 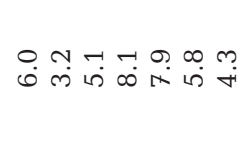 & 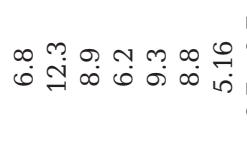 & 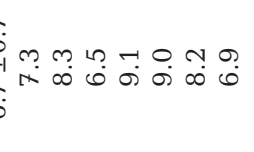 & 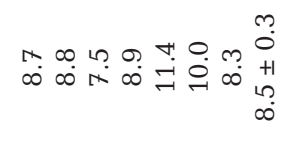 \\
\hline 高 & 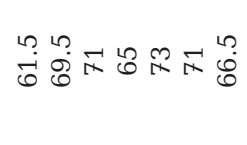 & 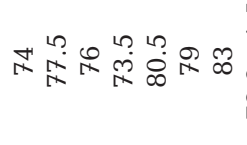 & $\underbrace{}_{0}$ & 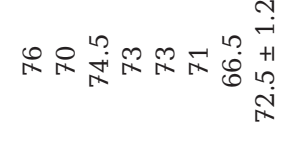 \\
\hline 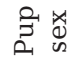 & 山㛧 $\sum \sum \Sigma \omega$ & $\Sigma 山 \Sigma 山 \Sigma 山 \Sigma$ & 山屾山 $\Sigma \Sigma$ & $\Sigma \Sigma \Sigma 山 匚 \Sigma 山$ \\
\hline 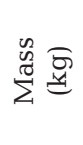 & 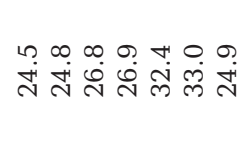 & 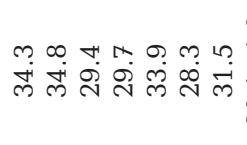 & 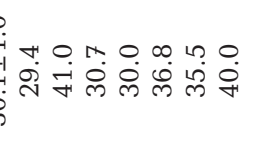 & 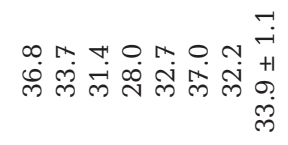 \\
\hline 莺 & 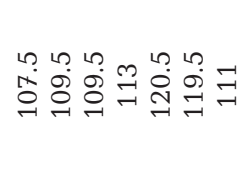 & 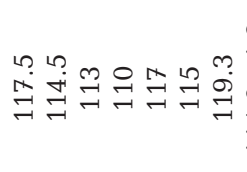 & 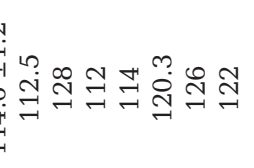 & 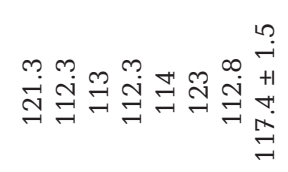 \\
\hline 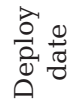 & 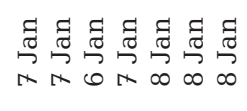 & 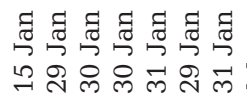 & 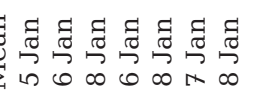 & 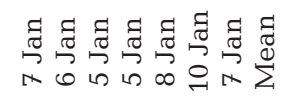 \\
\hline 迎 & $N \sim N N \sim N N$ & $\neg m \neg \neg N N \neg$ & $\neg N \neg n \rightarrow N-$ & $\neg r \neg m \neg \cdot r$ \\
\hline 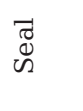 & 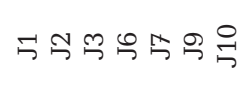 & 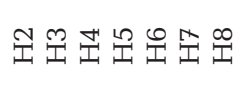 & 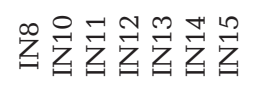 & 云艺㐕艺吕艺艺 \\
\hline : & 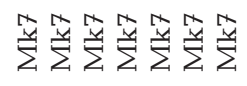 & 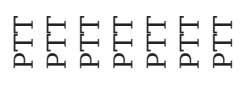 & 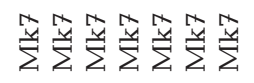 & 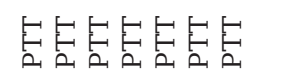 \\
\hline 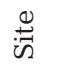 & 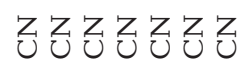 & 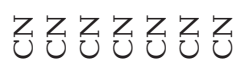 & 乙乙乙乙Z乙乙 & 乙ZZZZZる \\
\hline
\end{tabular}


seals at IN foraged within a $\sim 250 \mathrm{~km}$ arc to the $\mathrm{W}$ and SW of the colony $\left(224^{\circ}\right.$ to $\left.278^{\circ}\right)$. The foraging range of females was similar between the 2 colonies $\left(t_{10}=0.149\right.$, $\mathrm{p}>0.05)$, although the range in maximum distance traveled from CN was highly variable (114 to $448 \mathrm{~km}$, Table 2). Time spent in different bathymetric regions varied considerably between sites. Females at IN spent more time on the inner shelf (39\%) and in deep waters $(33 \%)$ than on the outer shelf $(14 \%)$ and shelf break $(12 \%)$. At $\mathrm{CN}$ females spent more time in deeper waters (36\%) and on the outer shelf $(26 \%)$ than on the inner shelf (17\%) and shelf break (16\%).

There is some evidence for device effects, with PTT females recording longer foraging trips than TDR females $\left(F_{1,25}=5.185, p=0.038\right.$, Table 3$)$. Consequently, we have only included TDR dive statistics in analyses for 7 females at each site (3 TDRs at CN and 1 TDR at IN failed, and 1 TDR at IN was not retrieved). Absolute and proportional transit and foraging phases of PTT females were similar between sites. Trip durations of TDR females at IN were significantly longer than those at CN (Table 3), as were transit times to the start of the first foraging bout ( $0.70 \mathrm{~d}$ cf. $\left.0.41 \mathrm{~d}_{;} \mathrm{t}_{11.87}=-2.370, \mathrm{p}=0.036\right)$. No significant differences in return transit phase, foraging phase length (time between transit phases), or the proportion of any phase in relation to trip duration were detected between sites, although the foraging phase tended to be longer at IN (Table 3). Foraging phase length was positively related to trip duration (Fig. 2).

The diving behaviour of females at each site (IN: 12840 dives, CN: 9852 dives) differed markedly when compared by ANOSIM, at $p=0.023$. Foraging trip duration, mean dive depth and the number of dives per hour accounted for $65.2 \%$ of the inter-site dissimilarity (Table 4). Trips were longer, dives deeper and the frequency of diving less at IN (Table 4). If trip duration was removed from the analysis, mean dive depth and dive frequency alone accounted for $52.4 \%$ of the dissimilarity between sites $(p=0.044)$. Mean dive depth was also significantly negatively correlated to foraging phase duration at IN $\left(\mathrm{r}_{1,7}=-0.904, \mathrm{p}=0.005\right)$ but not at

Table 3. Arctocephalus gazella. Mean durations and proportions of foraging and transit phases for females Antarctic fur seals from Iles Nuageuses (IN) and Cap Noir (CN). Sample sizes in parentheses

\begin{tabular}{|lrcrcrrrr|}
\hline Duration of trip & \multicolumn{2}{c}{ IN (7) } & \multicolumn{2}{c}{ CN (7) } & $t$ & $d f$ & $\mathrm{p}$ \\
\hline Phases (days) & Mean & SE & Mean & SE & & & \\
Transit phase 1 (T1) & 0.70 & 0.09 & 0.41 & 0.08 & -2.370 & 12 & 0.035 \\
\% time in T1 & 0.93 & 0.52 & 1.05 & 0.42 & -0.501 & 12 & 0.625 \\
Foraging phase (FP) & 6.78 & 0.37 & 5.14 & 0.74 & -1.991 & 12 & 0.070 \\
\% time in FP & 85.79 & 1.33 & 87.33 & 3.33 & -0.431 & 12 & 0.674 \\
Transit phase 2 (T2) & 0.41 & 0.17 & 0.20 & 0.09 & -1.102 & 12 & 0.292 \\
\% time in T2 & 6.16 & 2.48 & 6.23 & 3.08 & 0.018 & 12 & 0.986 \\
Total trip length & 7.89 & 0.38 & 5.76 & 0.67 & 2.768 & 12 & 0.017 \\
\hline
\end{tabular}

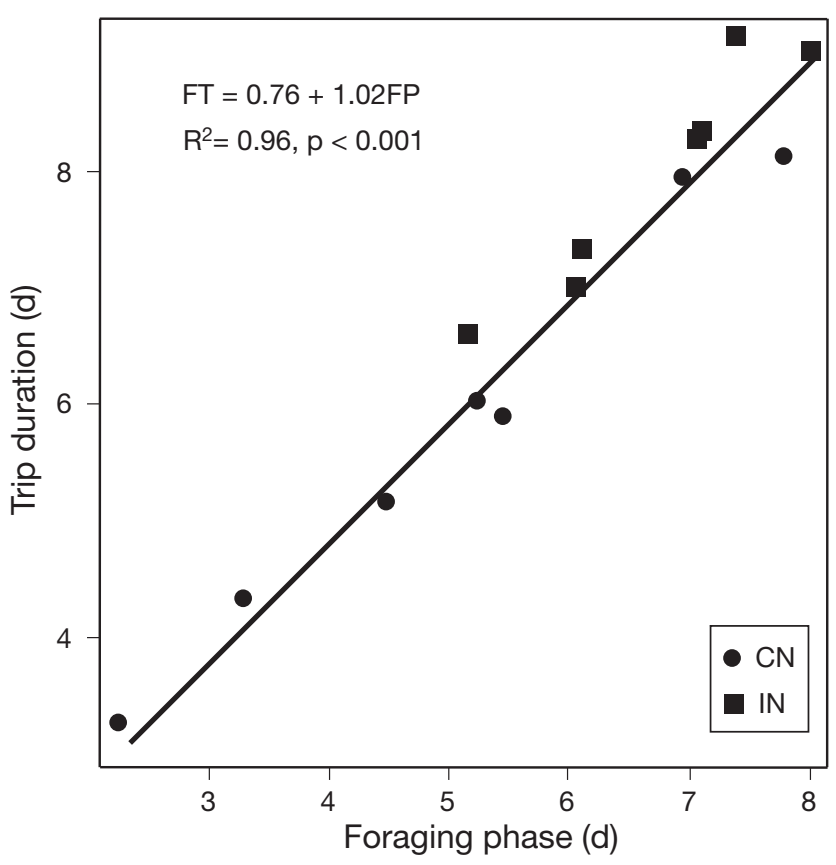

Fig. 2. Arctocephalus gazella. Relationship between trip duration and foraging phase length for females at Îles Nuageuses (IN) $(\mathrm{n}=7)$ and Cap Noir $(\mathrm{CN})(\mathrm{n}=7)$. FT: foraging trip duration; FP: foraging phase

$\mathrm{CN}\left(\mathrm{r}_{1,7}=0.425, \mathrm{p}>0.05\right)$. The timing of diving activity varied significantly between sites $(\mathrm{t}=-3.780, \mathrm{p}=0.008)$ with females at $\mathrm{CN}$ conducting $94.5 \pm 1.0$ (SE) \% of their diving nocturnally (Fig. 3, Table 4), compared with females from IN at $68.6 \pm 6.8 \%$ (33 to $87 \%$ ).

\section{Dietary preferences}

The frequency of occurrence of fish in the diet of female seals was high, with fish remains predominating at both study sites (83\% at IN and $89 \%$ at CN, Table 5). Evidence of cephalopod ingestion was considerably higher at $\mathrm{CN}$ than at IN, with beaks occurring in $67 \%$ of scats samples at CN (cf. $33 \%$ at IN). Crustaceans and other invertebrates were relatively uncommon by comparison, occurring in only one-third of samples from both sites.

In total 18 species of fish were recorded in the diet of female fur seals at IN and 15 species at CN (Table 6). The diet at both sites was dominated by myctophids, which accounted for $97.8 \%$ at IN and $98.8 \%$ at CN. In total, 1727 sagittal otoliths were recovered from the scats. Although the mean number of otoliths per scat was highest 
Table 4. Arctocephalus gazella. Mean comparisons and analysis of dissimilarity for dive parameters between female at Iles Nuageuses (IN) and Cap Noir (CN). PMG: pup mass gain during foraging trip (kg); PM: night

\begin{tabular}{|lccrrc|}
\hline Parameter & IN $(\mathrm{n}=7)$ & $\mathrm{CN}(\mathrm{n}=7)$ & $T$ & $\mathrm{p}$ & $\begin{array}{c}\text { Cumulative \% } \\
\text { dissimilarity }\end{array}$ \\
& & & & & \\
\hline 1. Trip length (d) & $7.89 \pm 0.38$ & $5.76 \pm 0.67$ & 2.768 & 0.017 & 26.9 \\
2. Mean depth (m) & $59.7 \pm 6.92$ & $43.1 \pm 1.44$ & 2.343 & 0.054 & 48.3 \\
3. Dives per hour & $9.5 \pm 0.9$ & $10.1 \pm 0.7$ & -0.470 & 0.646 & 65.2 \\
4. Mean dive duration (min) & $1.59 \pm 0.13$ & $1.29 \pm 0.06$ & 8.482 & 0.069 & 81.8 \\
5. Dives per bout & $10.1 \pm 0.3$ & $11.6 \pm 0.7$ & -1.971 & 0.083 & 93.9 \\
6. Time spent diving (\%) & $21.4 \pm 0.01$ & $24.2 \pm 0.01$ & 1.927 & 0.078 & \\
7. Proportion dives in bouts & $97.6 \pm 0.003$ & $97.1 \pm 0.004$ & 0.794 & 0.443 & \\
8. Proportion dives PM & $68.6 \pm 0.07$ & $94.5 \pm 0.01$ & -3.780 & 0.008 & \\
9. Time spent diving PM & $41.7 \pm 0.04$ & $58.0 \pm 0.02$ & -3.390 & 0.005 & \\
10. Prop Vertical depth PM & $50.0 \pm 6.5$ & $87.1 \pm 3.3$ & -5.103 & 0.000 & \\
11. Dives per hour PM & $20.7 \pm 3.6$ & $29.3 \pm 2.0$ & -2.127 & 0.055 & \\
PMG (TDR) & $3.1 \pm 0.3$ & $1.7 \pm 0.3$ & -3.049 & 0.011 & \\
PMG_FT (TDR) & $0.394 \pm 0.04$ & $0.278 \pm 0.02$ & -2.144 & 0.055 & \\
PMG_FC (TDR) & $0.312 \pm 0.04$ & $0.223 \pm 0.02$ & -2.548 & 0.027 & \\
\end{tabular}

Discriminant Function Analysis (DFA) of log-transformed abundance data (Wilks' Lambda = 0.2474 , approx. $\mathrm{F}_{11,16}=4.4249$, $\mathrm{p}<0.01)$. A backwards-stepwise DFA conducted on the same data indicated that 3 species, Gymnoscopelus nicholsi, Electrona carlsbergi and Gobionotothen acuta accounted for the distinction in diet between sites (Wilks' Lambda $=0.2526$, approx. $\mathrm{F}_{3,24}=23.6758, \mathrm{p}<0.001$ ). Using these 3 species as discriminators, only 2 of 28 samples were incorrectly assigned (Jackknife matrix 93\% success, IN: $100 \%$; CN: $86 \%$ ). at IN $(71.6 \pm 22.4$ [SE], range 1 to 238$)$, it did not differ significantly to that at CN $(51.8 \pm 11.6)$. Diet samples from IN were dominated by Gymnoscopelus nicholsi $(31.2 \%)$ and G. fraseri $(29.1 \%)$, with Krefftichthys anderssoni $(12.0 \%)$ also important to several individuals. At $\mathrm{CN}$ the prevalence of $G$. fraseri in the diet $(40.8 \%)$ outweighed that of all other species, while Electrona subaspera was also more common than in samples from IN (Table 6, Fig. 4).

A significant difference in the dietary composition between sites was detected by a complete linear
Foraging success

Body mass of pups was highly variable between individuals, ranging from 3.9 to $13.6 \mathrm{~kg}$ and 3.8 to $13.4 \mathrm{~kg}$ at $\mathrm{CN}$ and $\mathrm{IN}$, respectively. Male pups were heavier than females pups $\left(\mathrm{F}_{1,99}=26.50, \mathrm{p}<0.001\right)$ and IN pups were heavier than $\mathrm{CN}$ pups $\left(\mathrm{F}_{1,99}=7.22, \mathrm{p}<0.01\right.$, Table 7).

Mass gained by pups (PMG) after a maternal foraging trip was measured for pups of control animals (IN: $2.7 \pm$ $0.2[\mathrm{SE}] \mathrm{kg}, \mathrm{n}=8$; CN: $2.2 \pm 0.2 \mathrm{~kg}, \mathrm{n}=20$ ), PTT females

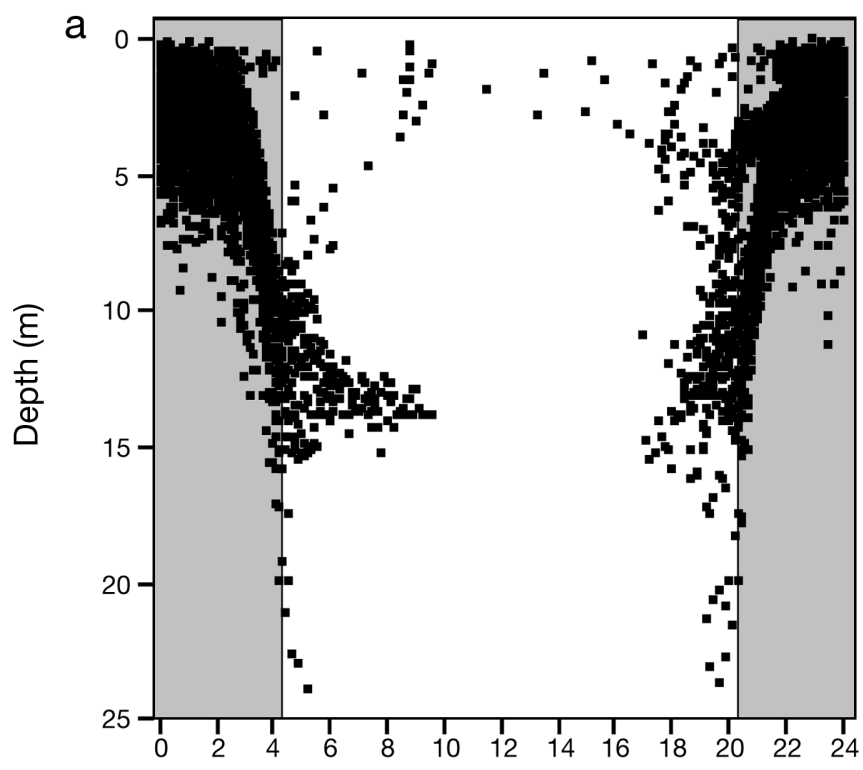

b

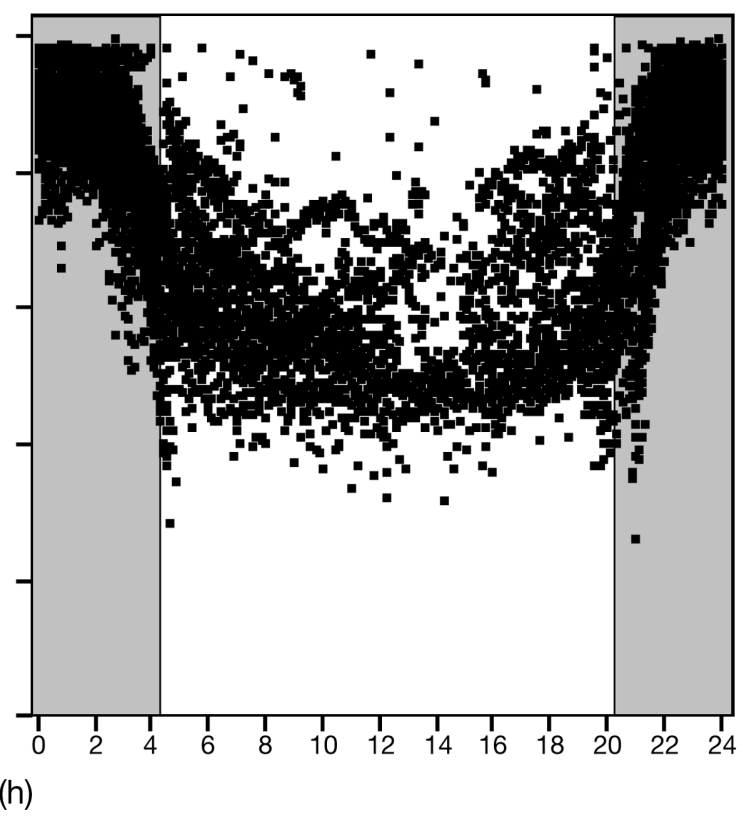

Fig. 3. Arctocephalus gazella. Diurnal variability in maximum dive depth at (a) Cap Noir (n= 7) and (b) îles Nuageuses (n = 7). Shaded regions denote night 
Table 5. Arctocephalus gazella. Frequency of occurrence by number and percentage of prey items recorded in Antarctic fur seal scats in January 2000 at Île de Croy (Iles Nuageuses) and Cap Noir, Kerguelen Archipelago. Number of scats sampled and the number containing prey items are in parentheses

\begin{tabular}{|c|c|c|c|c|}
\hline & \multicolumn{2}{|c|}{$\begin{array}{l}\text { Île de Croy } \\
(37 / 18)\end{array}$} & \multicolumn{2}{|c|}{$\begin{array}{l}\text { Cap Noir } \\
(26 / 18)\end{array}$} \\
\hline & $\mathrm{n}$ & $\%$ & $\mathrm{n}$ & $\%$ \\
\hline Fish & 15 & 83.3 & 16 & 88.9 \\
\hline Otoliths & 13 & 72.2 & 14 & 77.8 \\
\hline Eye lenses & 9 & 50.0 & 13 & 72.2 \\
\hline Bones & 14 & 77.8 & 12 & 66.7 \\
\hline Vertebrae & 10 & 55.6 & 11 & 61.1 \\
\hline $\begin{array}{l}\text { Myctophids } \\
\text { (scales or jaw bones) }\end{array}$ & 9 & 50.0 & 15 & 83.3 \\
\hline $\begin{array}{l}\text { Channichthyids } \\
\text { (jaw bones or opercles) }\end{array}$ & 1 & 5.6 & 0 & 0.0 \\
\hline Nototheniids (jaw bones) & 1 & 5.6 & 1 & 5.6 \\
\hline $\begin{array}{l}\text { Paradiplospinus gracilis } \\
\text { (teeth or vertebrae) }\end{array}$ & 1 & 5.6 & 0 & 0.0 \\
\hline $\begin{array}{l}\text { Harpagifer spinosus } \\
\text { (opercles) }\end{array}$ & 0 & 0.0 & 1 & 5.6 \\
\hline Cephalopods & 6 & 33.3 & 13 & 72.2 \\
\hline Beaks & 4 & 22.2 & 12 & 66.7 \\
\hline Eye lenses & 3 & 16.7 & 10 & 55.6 \\
\hline Gladii & 2 & 11.1 & 6 & 33.3 \\
\hline Crustaceans & 6 & 33.3 & 6 & 33.3 \\
\hline Themisto gaudichaudii & 5 & 27.8 & 4 & 22.2 \\
\hline Other amphipods & 3 & 16.7 & 0 & 0.0 \\
\hline Isopods & 1 & 5.6 & 1 & 5.6 \\
\hline Copepods & 0 & 0.0 & 1 & 5.6 \\
\hline \multicolumn{5}{|l|}{ Others } \\
\hline Nematodes & 12 & 66.7 & 10 & 55.6 \\
\hline Pebbles & 5 & 27.8 & 15 & 83.3 \\
\hline Mollusk shells & 2 & 11.1 & 1 & 5.6 \\
\hline Feathers (penguin) & 1 & 5.6 & 0 & 0.0 \\
\hline
\end{tabular}

(IN: $2.9 \pm 0.2 \mathrm{~kg}, \mathrm{n}=4 ; \mathrm{CN}: 2.8 \pm 0.2 \mathrm{~kg}, \mathrm{n}=6$ ) and TDR females (Table 4). PMG varied significantly in relation to unit type only at $\mathrm{CN}$, where pups of TDR females gained less mass than PTT pups $\left(\mathrm{F}_{32,2}=4.672, \mathrm{p}=0.016\right)$ while control pups were intermediate (Fig. 5a). Overall, pups of TDR females at IN gained more absolute mass and daily mass per trip and foraging cycle than pups at $\mathrm{CN}$ (Table 3). A multi-linear regression indicated trip duration (FT) and maternal length (ML) contributed equally to absolute PMG $(\mathrm{PMG}=0.318 \mathrm{FT}+0.098 \mathrm{ML}-10.534$, $\mathrm{p}<0.001, \mathrm{r}=0.939$, Fig. 5b).

\section{Regional habitat use}

Females from the previously unstudied colony at Pointe Suzanne on the Courbet Peninsula dispersed to the SE over the Kerguelen Plateau towards Heard Island (Fig. 6a). Effort in terms of seal hours is relatively evenly distributed, although more time was spent by seals at the outer reaches of the foraging zone on the inner/outer shelf boundary (SE) and the shelf break (E and S). Fig. 6b summarizes previous summer

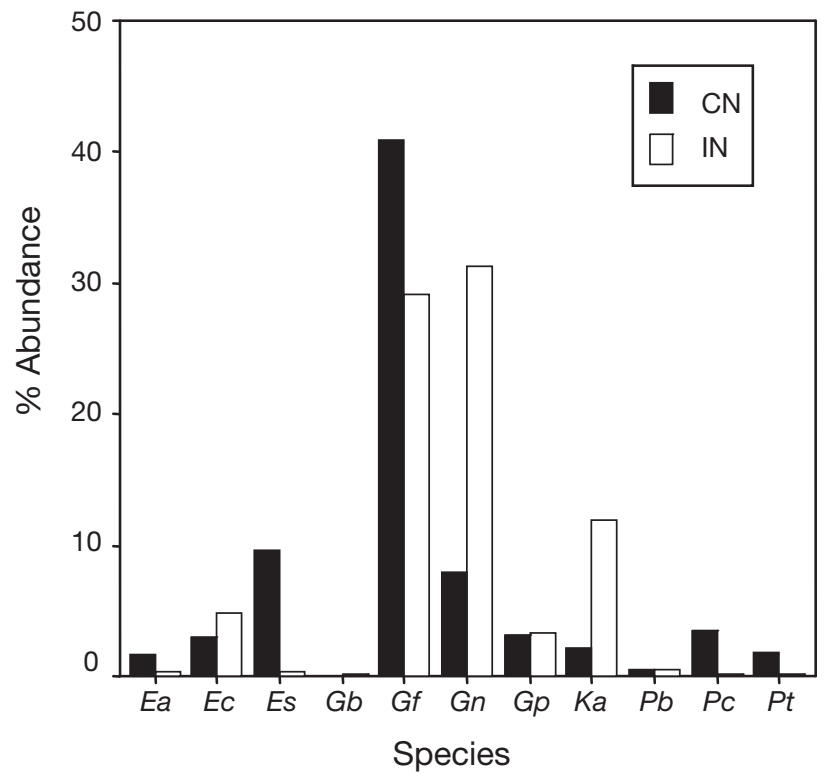

Fig. 4. Arctocephalus gazella. Percentage abundance of 11 myctophid species observed in the diet of Antarctic fur seals at Cap Noir (CN) and Îles Nuageuses (IN). Species abbreviations listed in Table 6

(January to March) tracking studies for 33 females from CN. Black cells demarcate the concentrated core foraging region common to seals in all $3 \mathrm{yr}$ (1998 to 2000 , Table 8 ), representing $9.7 \%$ of the total foraging region.

Finally, the foraging habitat use of seals from all 3 sites is presented in Fig. 6c. Foraging effort represents a combined 403 seal days for 54 individuals encompassing $28120 \times 20 \mathrm{~km}$ grid cells $\left(112400 \mathrm{~km}^{2}\right)$. Although not sampled simultaneously, the potential spatial overlap between the combined foraging range of $\mathrm{CN}$ seals and Pointe Suzanne females was high at $31.4 \%$; however, the overlap with the core $\mathrm{CN}$ region was low at $3 \%$. Bathymetric domains favoured by seals in order of importance were: outer shelf $(34.3 \%)$, deep water $(30 \%)$, inner shelf $(19.9 \%)$ and shelf break waters $(15.9 \%)$.

\section{DISCUSSION}

\section{Between site comparisons in the same year}

Spatial distribution and diving activity

Given the likely emigration of seals from IN to CN, some degree of similarity in foraging locations might be anticipated for seals from both sites. However, spatial overlap analyses of the foraging patterns of adult females from IN and CN in 2000 indicate complete foraging segregation at the $20 \times 20 \mathrm{~km}$ scale. Sample sizes 


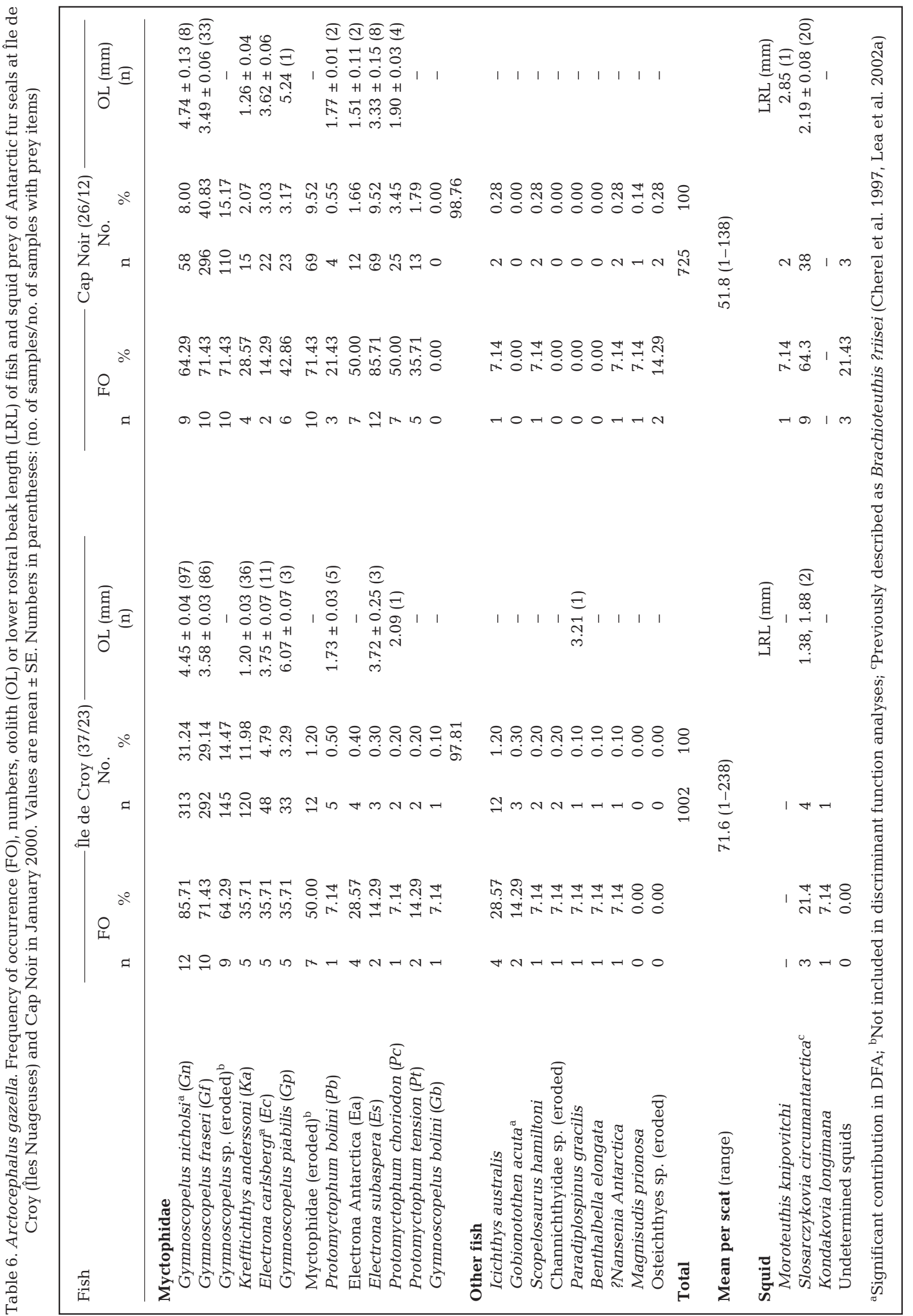


Table 7. Arctocephalus gazella. Mean pup body mass at Cap Noir (CN) and Iles Nuageuses (IN) in January 2000

\begin{tabular}{|lccc|}
\hline Colony & Pup sex & Body mass $( \pm$ SE, kg) & $\mathrm{n}$ \\
\hline CN & M & $7.64 \pm 0.25$ & 43 \\
CN & F & $6.48 \pm 0.19$ & 57 \\
IN & M & $8.21 \pm 0.25$ & 52 \\
IN & F & $7.08 \pm 0.21$ & 48 \\
\hline
\end{tabular}

for IN were small and consequently should be interpreted with some degree of caution. However, concurrent differences in diet, diving behaviour and indirect foraging success in terms of mass gain also support the idea of segregated foraging. Seals from IN concentrated their foraging effort westwards and to the SW along the shelf edge towards the Skiff Bank region in association with inner shelf and deep waters (Fig. 6). $\mathrm{CN}$ females, by comparison, dispersed widely from the colony to the east and south, focusing effort in deep water to the NE and along the outer shelf and southwards along the Kerguelen Plateau. The area to the NE of CN is highly productive, supporting one of the largest seasonal phytoplankton blooms in the Southern Ocean and high fish abundances associated with the flow of the Antarctic Polar Front (Duhamel et al. 2000, Blain et al. 2007). Consequently, it is regionally important for Antarctic fur seals and other marine predators (Guinet et al. 2001, Bost et al. 2002, Charrassin et al. 2004, Lea et al. 2006) and fisheries (Cherel et al. 1996). The only previous records of fur seals to the west of Kerguelen include large groups sighted at sea (Ensor \& Shaughnessy 1990), and more recently sightings and interactions of fur seals with fishing vessels (Capdeville 1997). The western slope of the Kerguelen shelf and the Skiff Bank region have been the focus of longline fisheries since the early 1990s (Duhamel 1992, Duhamel et al. 2005).

Clearly, local marine productivity is sufficiently high on both the east and west coasts of the island to enable distinct foraging segregation between the 2 colonies irrespective of their close proximity $(\sim 160 \mathrm{~km})$. Such a distance would take $\sim 18 \mathrm{hr}$ to cover at average surface swim speeds of $2.5 \mathrm{~m} \mathrm{~s}^{-1}$ (Watson 2007). Transit times to and from feeding areas and maximum distance traveled did not vary significantly for tracked seals (Fig. 1); however, there does appear to be some effect of carrying the PTT/TDR devices as foraging trips were longer for these females than those carrying only a tailmounted TDR. Transit time to feeding areas and foraging trip durations were, however, significantly longer for TDR females from IN than $\mathrm{CN}$, implying that the onset of foraging occurs earlier at $\mathrm{CN}$. In addition to increased foraging times, IN females spent more time diving during the day, to deeper depths $(\sim 60 \mathrm{~m})$ than their CN counterparts (see Lea et al. 2002b). It is likely that females are foraging over the extended shelf
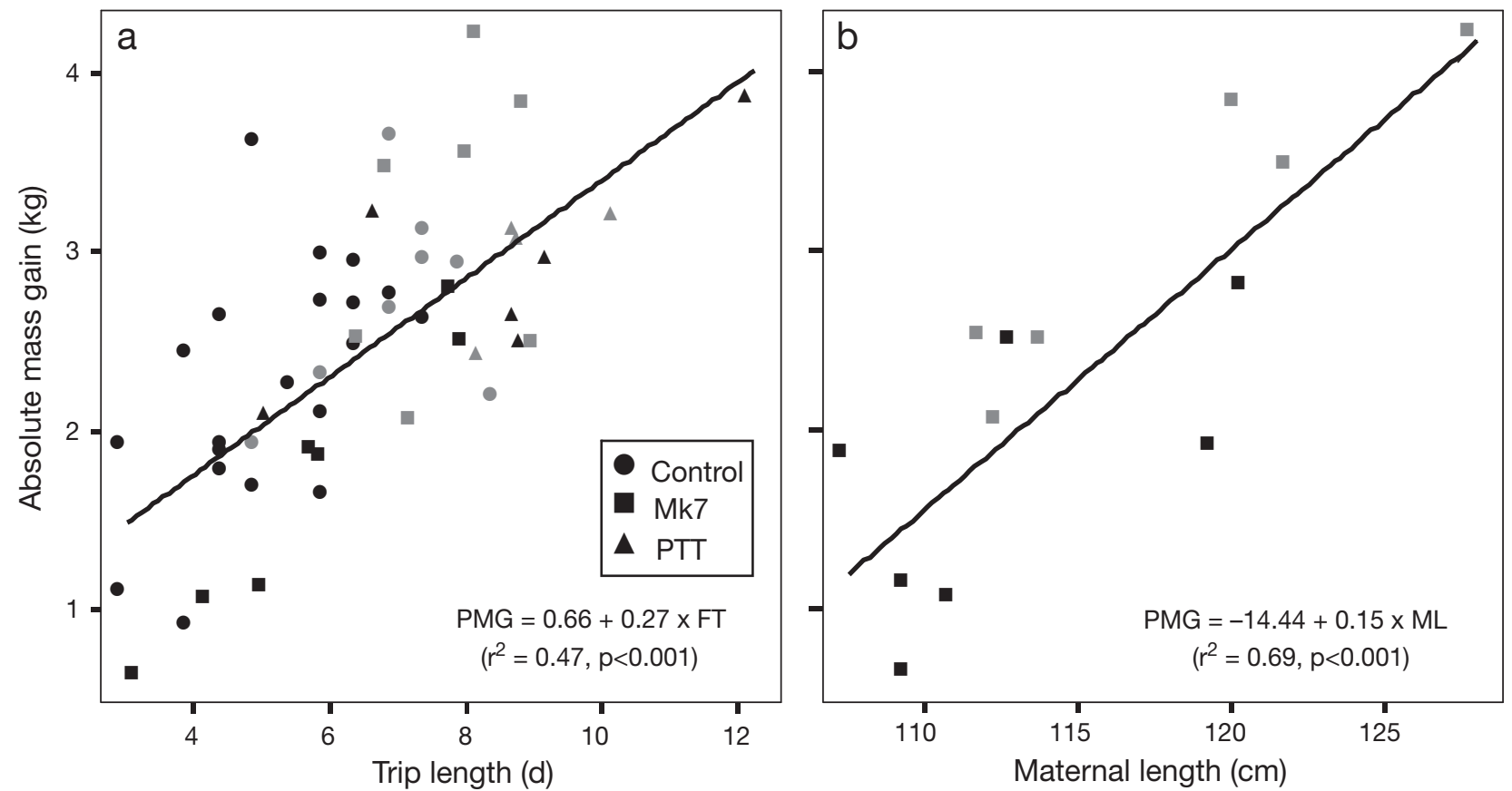

Fig. 5. Arctocephalus gazella. (a) Regression of absolute mass gained by pups (PMG) against maternal trip duration for control $(\mathrm{n}=28)$, TDR-equipped (Mk7; $\mathrm{n}=14)$ and PTT-equipped females $(\mathrm{n}=10)$; and (b) regression of PMG against maternal length for TDR equipped females; CN: Cap Noir; IN: Iles Nuageuses; black: CN; grey: IN 

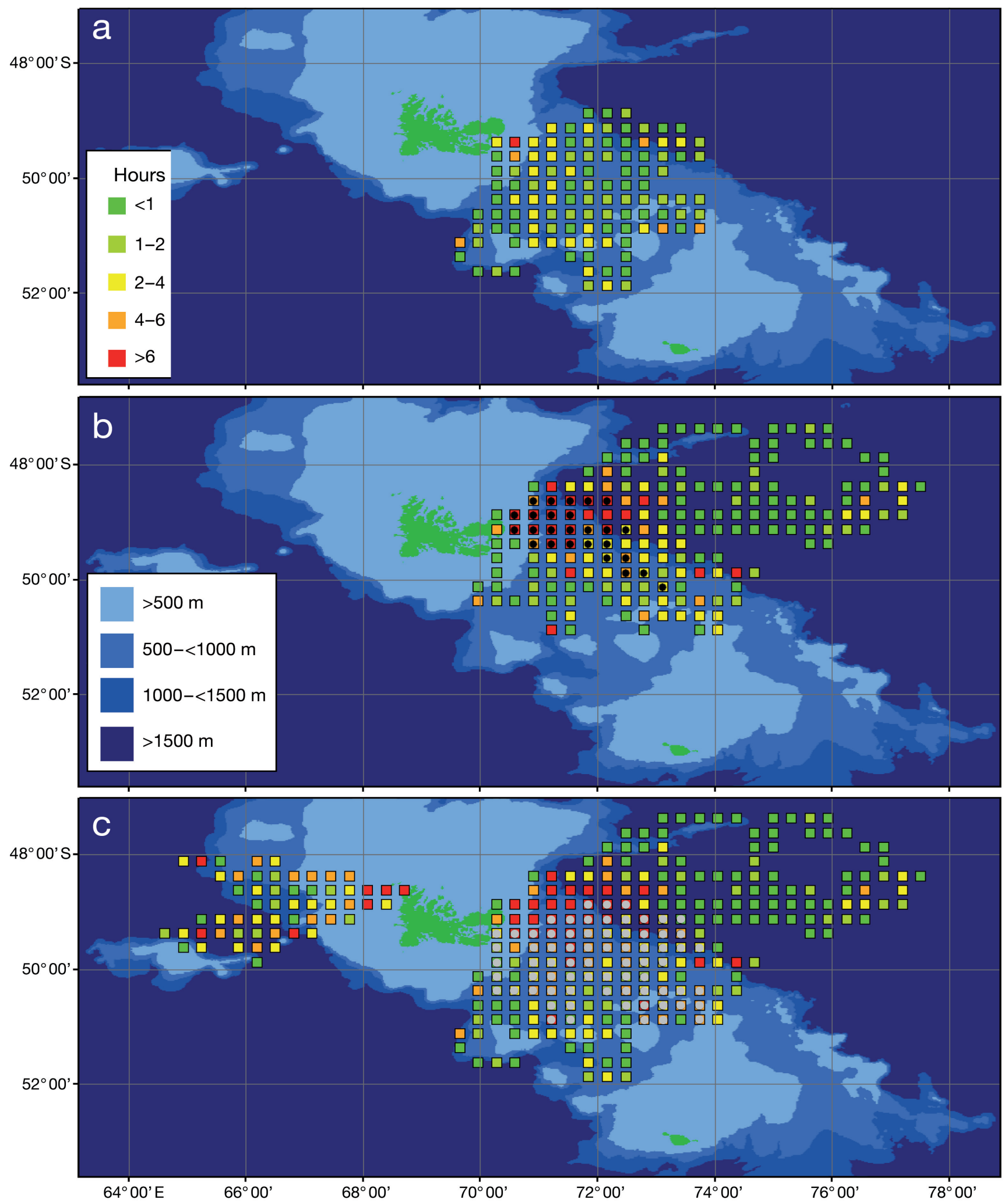

Fig. 6. Arctocephalus gazella. Time spent in seal hours per $20 \times 20 \mathrm{~km}$ grid by adult female Antarctic fur seals at: (a) Pointe Suzanne (2006, $\mathrm{n}=16$ ); (b) Cap Noir (1998-2000, $\mathrm{n}=33$ ); and (c) all 3 colonies at Îles Kerguelen in 1998, 1999, 2000 and 2006 $(\mathrm{n}=54)$. Black circles denote core summer foraging region for female seals from Cap Noir. Grey circles denote overlap between females from Cap Noir and Pointe Suzanne 
Table 8. Arctocephalus gazella. Habitat use and spatial foraging overlap for adult female Antarctic fur seals from Cap Noir (CN), Iles Nuageuses (IN) and Pointe Suzanne (PS)

\begin{tabular}{|lcccccc|}
\hline Colony comparisons & $\mathrm{n}$ & $\begin{array}{c}\text { Seal foraging } \\
\text { hours }\end{array}$ & $\begin{array}{c}\text { Number } \\
20 \times 20 \mathrm{~km} \text { cells }\end{array}$ & $\begin{array}{c}\text { Foraging area } \\
\left(\mathrm{km}^{2}\right)\end{array}$ & $\begin{array}{c}\text { Mean area } \\
\text { per seal }\left(\mathrm{km}^{2}\right)\end{array}$ & $\begin{array}{c}\text { Mean water } \\
\text { depth }\end{array}$ \\
\hline CN: Jan 00 & 7 & 1414 & 95 & 38000 & 5429 & $1611 \pm 102$ \\
IN: Jan 00 & 5 & 1090 & 55 & 22000 & 4400 & $1041 \pm 87$ \\
CN: summer 98-00 & 33 & 5694 & 184 & 73600 & 2230 & $1696 \pm 79$ \\
PS: summer 06 & 16 & 2892 & 113 & 45200 & 2825 & $839 \pm 51$ \\
All colonies & 54 & 9676 & 281 & 112400 & 2082 & $1443 \pm 58$ \\
Overlap & & \% overlap & & & Sum time spent $(\%)$ & 38.0 \\
Core CN: Summer 98-00 & - & 9.7 & 26 & 5600 & 11.8 & $854 \pm 114$ \\
Core CN \& PS & - & 3.6 & 14 & 28400 & 37.7 & $876 \pm 120$ \\
CN Summer \& PS & - & 31.4 & 71 & & & \\
\end{tabular}

region to the west of IN during daytime transits to productive shelf-break regions and access to preferred pelagic prey resources. Local oceanographic features, such as current movements, may contribute to the outward direction (Park et al. in press) taken by adult females in addition to an individual's prior knowledge of seasonal food resources (Bonadonna et al. 2001); the persistence of oceanic prey 'hot spots' may also enable predators to reduce foraging effort (Gende \& Sigler 2006).

\section{Dietary segregation}

Identifiable squid remains occurred in more than $70 \%$ of scats at $\mathrm{CN}$ and were relatively rare by comparison at IN (33\%). The primary species taken by $\mathrm{CN}$ females, Slosarczykovia circumantarctica, is a relatively small, abundant, pelagic migratory species from Antarctica (Cherel \& Hobson 2005). Commonly consumed by predators - including fish, seabirds, seals and penguins - at both Crozet and Kerguelen (Cherel et al. 2004), it was also the primary squid species taken by fur seals at CN during previous diet studies (Lea et al. 2002a). Although squid consumption is likely underestimated by the faecal analysis technique employed (as many squid beaks are regurgitated, Kirkman et al. 2000), fur seal diet at Îles Kerguelen is dominated by myctophid fish.

The fish assemblage in the Polar Frontal zone waters near Kerguelen is comprised primarily of Myctophidae (Duhamel et al. 2000) which constitute the largest biomass in the Southern Ocean after krill (Loots et al. 2007). The most numerous of the circum-Antarctic species are Gymnoscopelus nicholsi and Electrona antarctica (Sabourenkov 1990). Myctophids are an important dietary component for many sub-Antarctic marine predators, notably the king penguin (Bost et al. 2002) and fur seals - in particular at Kerguelen (Cherel et al.
1996, Lea et al. 2002a, Lea et al. 2006) and Heard island (Green et al. 1989). At IN in 1994, G. nicholsi was the most numerous prey item taken by male, female and juvenile fur seals (Cherel et al. 1996). In 2000, the diet of AFS at both sites was dominated by myctophids. We confirm the importance of $G$. nicholsi in the diet of adult females at IN and highlight the common occurrence of G. fraseri at CN and IN. G. nicholsi is mesopelagic/ epibenthic, generally distributed along the shelf breaks and over the shelf at depth (Duhamel et al. 2005), migrating vertically to the top $100 \mathrm{~m}$ at night to feed (Pusch et al. 2004). Given the high occurrence of G. nicholsi in the diet of fur seals at IN, and its general absence at $\mathrm{CN}$, it is reasonable to assume that shelf waters W and SW of IN are prime habitat for G. nicholsi. Rare research surveys to this productive region corroborate the existence of G. nicholsi (Koubbi et al. 2000) here and to the NE of Kerguelen along the shelf break (Duhamel et al. 2005). G. nicholsi is comparable in calorific content to $G$. fraseri per gram at $\sim 10 \mathrm{~kJ}$ (Lea et al. 2002c); however, the average size of fish consumed varies considerably. A $7.5 \mathrm{~cm} \mathrm{G}$. fraseri yields approximately $45 \mathrm{~kJ}$ while an $11 \mathrm{~cm} \mathrm{G}$. nicholsi yields 3 times more energy, around $145 \mathrm{~kJ}$ (see Lea et al. 2002c). This discrepancy may offset the longer transit times, foraging trips and deeper dives recorded for IN seals. Milk fat content also increases concomitantly with increasing myctophid content in the diet, potentially further offsetting increased foraging effort by IN females by increasing the calorific content of their milk available to their pups (Lea \& Dubroca 2003).

Recently Reid et al. (2006) have shown that local marine topography and oceanographic variability likely explain the temporal and spatial variability recorded in AFS diet in the Atlantic sector of the Southern Ocean. Zeppelin \& Ream (2006) have confirmed such influences, showing that colony-specific dietary preferences of northern fur seals persist over many years and are indicative of foraging in distinct hydro- 
graphic domains. The differences in habitat use and prey selection observed between $\mathrm{CN}$ and IN would be further clarified by simultaneous prey surveys in east and west coast bathymetric domains utilized by fur seals.

\section{Provisioning success}

Pup body mass and mass gained per foraging trip were both significantly higher at IN than at $\mathrm{CN}$, perhaps indicating higher prey availability at IN. Although median birth dates have not been measured at either site, they are similar at both South Georgia and Marion Island (see Hofmeyr et al. 2007), which are much farther apart, indicating that pup body mass data may constitute a valid index of relative prey availability. Daily PMG per foraging trip was also significantly higher at IN, with longer, potentially older, females transferring more mass to pups than smaller females. This finding implies that experienced females may be more efficient foragers, and that body size also confers advantages in terms of energy transfer rates (Beauplet \& Guinet 2007). Females at CN dive more frequently during restricted bouts of night diving (29 dives $\mathrm{h}^{-1}$ ), while IN females tend to spend less time diving over the course of foraging trips, due to longer transit times. Foraging trips at $\mathrm{CN}$ averaged $5.7 \mathrm{~d}$, while IN females averaged $7.9 \mathrm{~d}$. So although mass gain rates were higher at IN, overall, pup growth rates at both sites may be similar due to the discrepancies in mean foraging trip length. Pups at CN would have 20.7 feeding events over the 4 mo lactation period compared with 15.2 feeding events at IN. At this stage, without the benefit of multi-year studies, it is difficult to state whether one breeding site promotes more favourable pup rearing conditions than the other. However, the rapid population growth of colonies on both coasts suggests that fur seals have not yet attained carrying capacity at Îles Kerguelen.

\section{Multi-year and site comparisons of Antarctic fur seal habitat use}

Niche overlap theory predicts that overlap should decrease with increasing environmental variability and with increasing numbers of species (Pianka 1974). The waters surrounding Kerguelen are highly dynamic and variable in terms of local productivity. This is reflected in the inter-annual variability of foraging zones utilized by female AFS at CN (Lea et al. 2006). Although seals concentrated foraging in a core area along the shelf break to the NE of the colony in all years, in 2000, a year of high pup growth at CN, much foraging effort was focused to the SE along the Kerguelen Plateau (Lea \& Dubroca 2003, Lea et al. 2006). This region is also an important foraging habitat for king penguins Aptenodytes patagonicus breeding on the east coast of Kerguelen (Bost et al. 2002). Potential competition between these 2 myctophid specialists is minimized by the diel feeding habits of both predators, with king penguins feeding primarily during the day at greater depths than the nocturnal fur seals. King penguins have been shown to access the cold thermocline waters below $100 \mathrm{~m}$ along the eastern edge of the Kerguelen Plateau (Charrassin et al. 2004), while fur seals tend to dive in the upper $50 \mathrm{~m}$ of the water column, only descending to greater mean depths in years of anomalously warm sea surface temperatures and reduced prey availability (Lea et al. 2006).

The potential overlap between Pointe Suzanne seals and all $\mathrm{CN}$ individuals occurs primarily in this region over outer shelf waters. Animals from Pointe Suzanne (2006) and CN (1998 to 2000) were not tracked simultaneously and, consequently, interpretation of overlap between sites is somewhat limited. Although it is unclear whether overlap is persistent or more likely in years of high and dispersed prey availability, seals from the Courbet Peninsula clearly utilize common inner and outer shelf domains. Our findings concur with those on other central place foraging marine predators. Trathan et al. (2006) showed that overlap in foraging zones was high for closely adjacent macaroni penguin colonies and minimal for more distant colonies. Boyd et al. (2002) reported no overlap for AFS females from colonies $300 \mathrm{~km}$ apart, which is well within the foraging range of the species, while Robson et al. (2004) noted greater overlap between northern fur seals from colonies on the same island than between islands which were only $72 \mathrm{~km}$ apart.

Population-level foraging distribution patterns and habitat use by AFS at Îles Kerguelen in 1998, 1999, 2000 and 2006 confirm the importance of inner and shelf regions, and deep water habitats within a $250 \mathrm{~km}$ range of breeding colonies. Guinet et al. (2001) predicted the likely habitat use of central place foraging AFS at Îles Kerguelen based on bathymetry, oceanographic features and fish distribution for 1998. The actual foraging distribution of Kerguelen seals (this study) confirms these predictions when distance to the colony is excluded, indicating a preference for shelf and shelf break areas to the SW (IN) and $\mathrm{E}$ and $\mathrm{NE}(\mathrm{CN})$.

\section{CONCLUSIONS}

Habitat use by the increasing fur seal population at Îles Kerguelen is variable between colonies and between years. Competition between conspecifics from 
west and east coast colonies appears low, with no spatial overlap and distinct differences in the species composition observed within the diet. Despite the close proximity of these colonies, indications are that high relative prey densities adjacent to the breeding colonies and observed differences within the diving behaviour are sufficient to prevent inter-colony resource competition. Thus, it also appears that high local prey densities also over-ride the potential transfer of knowledge of favourable foraging sites transmitted through emigration between islands. The potential for inter-species competition with king penguins is minimized on the east coast through temporal and behavioural differences in diving. Although both species utilize the same regions, foraging times and prey species preferences differ markedly between the myctophid specialists. Overlap between years and between east coast colonies suggests a continuum of foraging zones between $\mathrm{CN}$ and Pointe Suzanne colonies, which may be variable in response to annual changes in oceanographic parameters. Core habitat regions were common to seals from $\mathrm{CN}$ in all summers, and although relatively small in size, they are important in terms of time spent foraging. Future management of commercial fisheries in the waters surrounding Kerguelen might consider the possibility of differential impacts on the foraging behaviour of females from various colonies, given the importance of locally productive regions to fur seal breeding success.

Acknowledgements. All research was conducted with the support of and under research and ethics permits from the Institut Polaire Paul Emîle Victor (IPEV). We also acknowledge the financial and logistic support of IPEV and the Terres Australes et Antarctiques Francaises (TAAF). A. Lamalle and EPEV staff installed the field base for research at îles Nuageuses. C. Chaillon and S. Samtmann provided much needed assistance in the field. The crew of La Curieuse provided further logistic support. The Sea World Research and Rescue Foundation (Australia) and the Australian Antarctic Scientific Advisory Committee also provided financial support. Bristol-Myers Squibb supplied bleaching products.

\section{LITERATURE CITED}

Baird PH (1991) Optimal foraging and intraspecific competition in the tufted puffin. Condor 93:503-515

Barlow KE, Boyd IL, Croxall JP, Reid K, Staniland IJ, Brierley AS (2002) Are penguins and seals in competition for Antarctic krill at South Georgia? Mar Biol 140:205-213

Beauplet G, Guinet C (2007) Phenotypic determinants of individual fitness in female fur seals: larger is better. Proc $\mathrm{R}$ Soc Lond B 274:1877-1883

Bester MN (1981) Fur seals Arctocephalus gazella and leopard seals Hydrurga leptonyx at the Courbet Peninsula, Kerguelen. S Afr J Antarct Res 10/11:35-37

Blain S, Quéguiner B, Armand L, Belviso S and others (2007) Effect of natural iron fertilization on carbon sequestration in the Southern Ocean. Nature 446:1070-1074
Bonadonna F, Lea MA, Guinet C (2000) Foraging routes of Antarctic fur seals (Arctocephalus gazella) investigated by the concurrent use of satellite tracking and time-depth recorders. Polar Biol 23:149-159

Bonadonna F, Lea MA, Dehorter O, Guinet C (2001) Foraging ground fidelity and route-choice tactics of a marine predator: the Antarctic fur seal (Arctocephalus gazella). Mar Ecol Prog Ser 223:287-297

Bost CA, Zorn T, Le Maho Y, Duhamel G (2002) Feeding of diving predators and diel vertical migration of prey: King penguins' diet versus trawl sampling at Kerguelen Islands. Mar Ecol Prog Ser 227:51-61

Boyd IL, Staniland IJ, Martin AR (2002) Distribution of foraging by female Antarctic fur seals. Mar Ecol Prog Ser 242: 285-294

Budd GM, Downes MC (1969) Population increase and breeding in the Kerguelen fur seal, Arctocephalus tropicalis gazella, at Heard Island. Mammalia 33:58-67

Call KA, Ream RR, Johnson D, Sterling JT, Towell RG (in press) Foraging route tactics and site fidelity of adult female northern fur seals (Callorhinus ursinus) around the Pribilof Islands. Deep Sea Res II

Capdeville D (1997) Interaction of marine mammals with the longline fishery around the Kerguelen Islands (Division 58.5.1) during the 1995/96 cruise. CCAMLR Sci 4: $171-174$

Charrassin JB, Bost CA, Putz K, Lage J, Dahier T, Zorn T, Le Maho Y (1998) Foraging strategies of incubating and brooding King penguins Aptenodytes patagonicus. Oecologia 114:194-201

Charrassin JB, Park Y, Le Maho Y, Bost CA (2004) Fine resolution 3D temperature fields off Kerguelen from instrumented penguins. Deep-Sea Res I 51:2091-2103

Cherel Y, Hobson KA (2005) Stable isotopes, beaks and predators: a new tool to study the trophic ecology of cephalopods, including giant and colossal squids. Proc R Soc Lond B 272:1601-1607

> Cherel Y, Weimerskirch H, Duhamel G (1996) Interactions between longline vessels and seabirds in Kerguelen waters and a method to reduce seabird mortality. Biol Conserv 75:63-70

Cherel Y, Guinet C, Tremblay Y (1996) Fish prey of Antarctic fur seals Arctocephalus gazella at Ile de Croy, Kerguelen. Polar Biol 17:87-90

> Cherel Y, Duhamel G, Gasco N (2004) Cephalopod fauna of subantarctic islands: new information from predators. Mar Ecol Prog Ser 266:143-156

Duhamel G (1992) Exploratory longline fishing around the Kerguelen Islands (Division 58.5.1). Description of the fishing effort, catchability and target size of Dissostichus eleginoides. Report No. WG-FSA-92/31, CCAMLR, Hobart, Australia

Duhamel G, Koubbi P, Ravier C (2000) Day and night mesopelagic fish assemblages off the Kerguelen Islands (Southern Ocean). Polar Biol 23:106-112

Duhamel G, Gasco N, Davaine P (2005) Poissons des îles Kerguelen et Crozet. Guide régional de l'océan Austral, Vol 63. Muséum national d'Histoire naturelle, Paris

Ensor PH, Shaughnessy PD (1990) Fur seals over the Kerguelen Plateau and elsewhere in the Southern Ocean. Polar Biol 10:481-483

Forero MG, Tella JL, Hobson KA, Bertellotti M, Blanco G (2002) Conspecific food competition explains variability in colony size: a test in Magellanic penguins. Ecology 83:3466-3475

Gende SM, Sigler MF (2006) Persistence of forage fish 'hot spots' and its association with foraging Steller sea lions 
(Eumetopias jubatus) in southeast Alaska. Deep-Sea Res II 53:432-441

Georges JY, Guinet C (2000) Maternal care in the subantarctic fur seals on Amsterdam Island. Ecology 81:295-308

Green K, Williams R, Burton HR (1989) The diet of Antarctic fur seals during the breeding season at Heard Island. Antarct Sci 1:317-324

Guinet C, Lea MA, Goldsworthy SD (2000) Mass change in Antarctic fur seal (Arctocephalus gazella) pups in relation to maternal characteristics at the Kerguelen Islands. Can J Zool 78:476-483

Guinet C, Dubroca L, Lea MA, Goldsworthy S, Cherel Y, Duhamel G, Bonadonna F, Donnay JP (2001) Spatial distribution of foraging in female Antarctic fur seals Arctocephalus gazella in relation to oceanographic variables: a scale dependant approach using geographic information systems 219:251-264

Hofmeyr GJG, Bester MN, Pistorius PA, Mulaudzi TW and others (2007) Median pupping date, pup mortality and sex ratio of fur seals at Marion Island. S Afr J Antarct Res 37:1-8

Jouventin P, Stonehouse B (1985) Biological survey of Ile de Croy, Iles Kerguelen, 1984. Polar Rec 22:688-691

Jouventin P, Stahl JC, Weimerskirch H (1982) La recolonisation des Iles Crozet par les otaries (Arctocephalus tropicalis et A. gazella). Mammalia 46:505-514

Kirkman SP, Wilson W, Klages NTW, Bester MN, Isaksen K (2000) Diet and estimated food consumption of Antarctic fur seals at Bouvetoya during summer. Polar Biol 23: 745-752

Koubbi P, Duhamel G, Hebert C (2000) Role of bay, fjord and seamount on the early life history of Lepidonotothen squamifrons from the Kerguelen Islands. Polar Biol 23: 459-465

Lea MA, Dubroca L (2003) Fine-scale linkages between diving behaviour of Antarctic fur seals and oceanographic features in the southern Indian Ocean. ICES J Mar Sci 60: 990-1002

Lea MA, Cherel Y, Guinet C, Nichols PD (2002a) Antarctic fur seals foraging in the polar frontal zone: inter-annual shifts in diet as shown from faecal and fatty acid analyses. Mar Ecol Prog Ser 245:281-297

Lea MA, Hindell M, Guinet C, Goldsworthy SD (2002b) Variability in the diving activity of Antarctic fur seals, Arctocephalus gazella, at Iles Kerguelen. Polar Biol 25: 269-279

Lea MA, Nichols PD, Wilson G (2002c) Fatty acid composition of lipid-rich myctophids and mackerel icefish (Champsocephalus gunnari) - Southern Ocean food-web implications. Polar Biol 25:843-854

Lea MA, Guinet C, Cherel Y, Duhamel G, Dubroca L, Pruvost $\mathrm{P}$, Hindell M (2006) Impacts of climatic anomalies on provisioning strategies of a Southern Ocean predator. Mar Ecol Prog Ser 310:77-94

Loots C, Koubbi P, Duhamel G (2007) Habitat modelling of Electrona antarctica (Myctophidae, Pisces) in Kerguelen by generalized additive models and geographic information systems. Polar Biol 30:951-959
McCafferty DJ, Boyd IL, Walker TR, Taylor RI (1998) Foraging responses of Antarctic fur seals to changes in the marine environment. Mar Ecol Prog Ser 166:285-299

Mori Y, Boyd IL (2004) The behavioural basis for nonlinear functional responses and optimal foraging in Antarctic fur seals. Ecology 85:398-410

Orians GH, Pearson NE (1979) On the theory of central place foraging. In: Horn DJ, Stairs ET, Mitchell RT (eds) Analysis of ecological system. Ohio State University Press, Columbus, p 155-177

Page B, Welling A, Chambellant M, Goldsworthy SD, Dorr T, van Veen R (2003) Population status and breeding season chronology of Heard Island fur seals. Polar Biol 26: 219-224

Page B, McKenzie J, Sumner MD, Coyne M, Goldsworthy SD (2006) Spatial separation of foraging habitats among New Zealand fur seals. Mar Ecol Prog Ser 323:263-279

Park Y, Roquet F, Durand I, Fuda JL (in press) Large scale circulation over and around the Northern Kerguelen Plateau. Deep Sea Res II, doi: 10.1016/j.dsr2.2007.12.030

Pianka ER (1974) Niche overlap and diffuse competition. Proc Natl Acad Sci USA 71:2141-2145

Pusch C, Hulley PA, Kock KH (2004) Community structure and feeding ecology of mesopelagic fishes in the slope waters of King George Island (South Shetland Islands, Antarctica). Deep-Sea Res 51(I):1685-1708

Reid K, Davis D, Staniland IJ (2006) Spatial and temporal variability in the fish diet of Antarctic fur seal (Arctocephalus gazella) in the Atlantic sector of the Southern Ocean. Can J Zool 84:1025-1037

Robson BW, Goebel ME, Baker JD, Ream RR and others (2004) Separation of foraging habitat among breeding sites of a colonial marine predator, the northern fur seal (Callorhinus ursinus). Can J Zool 82:20-29

Sabourenkov EN (1990) Mesopelagic fish of the Southern Ocean-summary results of recent Soviet studies. CCAMLR Sel Sci Pap 1990:433-445

Salamolard M, Weimerskirch H (1993) Relationship between foraging effort and energy requirement throughout the breeding season in the wandering albatross. Funct Ecol 7:643-652

Sterling JT, Ream RR (2004) At-sea behavior of juvenile male fur seals (Callorhinus ursinus). Can J Zool 82: 1621-1637

Sumner MD (2006) trip: Spatial analysis of animal track data. $\mathrm{R}$ package version 0.0.8.

Trathan PN, Green C, Tanton J, Peat H, Poncet J, Morton A (2006) Foraging dynamics of macaroni penguins at South Georgia during brood-guard. Mar Ecol Prog Ser 323: 239-251

Tremblay Y, Cherel Y (2003) Geographic variation in the foraging behaviour, diet and chick growth of rockhopper penguins. Mar Ecol Prog Ser 251:279-297

Watson L (2007) Velocity as a measure of foraging success in lactating Antarctic fur seals (Arctocephalus gazella). Honours thesis, University of Tasmania

Zeppelin TK, Ream RR (2006) Foraging habitats based on the diet of female northern fur seals (Callorhinus ursinus) on the Pribilof Islands, Alaska. J Zool (Lond) 270:565-576
Editorial responsibility: Otto Kinne, Oldendorf/Luhe, Germany
Submitted: August 1, 2007; Accepted: October 26, 2007

Proofs received from author(s): March 20, 2008 